\title{
In Vitro Methods of Preserving Rusts
}

\author{
Marcos Cesar Mottin*, Samara Brandão Queiroz, Edleusa Pereira Seidel, Monica Carolina Sustakowski and \\ Katiely Aline Anschau
}

State University of West of Paraná-Unioeste, Brazil

Submission: May 01, 2017; Published: May 23, 2017

"Corresponding author: Marcos Cesar Mottin, State University of West of Paraná-Unioeste, Center of Agricultural Sciences, Campus Rondon, Pernanbuco Street, 1777, CEP: 85960-000, Center, Marechal Cândido Rondon, Brazil, Tel: 554499995 9886; Email: marcos.c.mottin@hotmail.com

\begin{abstract}
Summary
The rust fungi that are considered obligate parasites. Thus, the lack of an efficient method of preserving these rust causative agents in vitro for a long period of time is considered a barrier to the studies of the physiology, genetics and pathogenicity. Thus, for the purpose of research, the maintenance and/or multiplication of the fungus is obtained through successive inoculations in host plants. Thus, this study aimed to carry out the survey of information on methods of cultivation/preservation in vitro rusts. We conclude that the preservation possibilities in vitro rust for a long period of time is still very vague and there is no precise methodology and concrete about it. There are some methodologies that allow the preservation of rust, however, for a short period of time. We still need more studies on these methodologies and their performance in practice in order to achieve a concrete methodology for the preservation of rusts in vitro as well as there is for other microorganisms.
\end{abstract}

Keywords: Fungi; Methodologies; Pathogens

\section{Introduction}

In order to maintain the equilibrium of the agroecossystem, disease management must be carried out in order to reduce the damages caused by these pathogens to commercial crops, among them, a prominence in relation to rust-causing fungi, due to their complexity and difficulty of control.

The rust-causing fungi are considered obligatory parasites, that is, they need a living host (biotrophic) so they can grow and reproduce, thus completing their life cycle [1]. Thus, the lack of an efficient method of preserving these causal rust agents in vitro for a long period of time is considered a barrier to the studies of the physiology, genetics and pathogenicity [2] and the [3]. In the present study, it is possible to compare the different species, the identification of new breeds, and laboratory studies.

Thus, for the purpose of research, the maintenance and/ or multiplication of the fungus is obtained through successive inoculations in host plants [4]. In addition, the preservation of uredospores can be carried out at a low temperature, obtaining the genetic preservation of the isolate, besides reducing the time, physical space and manpower in the maintenance of the pathogen [5].

Several proposals for uredymospores preservation methodologies are described in the literature for some rust [6].
Thus, this study aimed to carry out the survey of information on methods of cultivation/preservation in vitro rusts.

\section{In Vitro Methods of Preserving Rusts}

The cultivated plants are constantly attacked by a series of diseases, which interfere negatively the productivity of the species. Among these diseases, rusts stand that are caused by several species of fungi, particularly of the order and Pucciniales Pucciniaceae family [7].

These pathogens, although attacking different species of plants, have similar symptoms in each of them, small leaf blotches of brown to dark brown in color, and can occupy large areas (petioles, pods, stems) which, over time, yellow and fall, In the case of leaves [8]. The plants that undergo the attacks have their photosynthetic production compromised, once the pathogen develops they feed on their living structures, thus, the leaves fall early, decreasing their final production [9].

In addition to the high availability of plants, the pathogens that represent rust also find the favorable climate in our country to develop and cause infection, besides other factors such as monoculture, non-rotation of active principles, favor establishment Of individuals [10]. 
It can be said that the only way to control this disease is through registered fungicides, which significantly increases the cost of production of the producers, as well as subjecting them to risks of contamination to their own health, as well as the fauna and flora in which These products are being handled. Another issue to be posed is that and depending on the successive applications, certain pathogens have to be made tolerant to some fungicides [11].

Another way of controlling these pathogens would be through the use of resistant varieties, which would be an efficient and quite feasible method, as well as preventive, however, these varieties are still commercially unavailable or unavailable in the market [12].

In an attempt to reduce the use of fungicides, minimizing the problem of environmental and human contamination, some scholars have invested their research in tests with biofungicides through plant extracts, however, a bottleneck of these surveys has been the maintenance of in vitro pathogens [13].

The pathogenic fungi that cause rust are classified as bryophytes, surviving only in living plant tissue, thus hindering the advancement of more advanced research in relation to their biology, cycle, variability, resistance, and so on [14].

Some researchers have been testing methods of creating some species in vitro, in an attempt to achieve enable the further expansion of such studies. The main objective is to imitate in the culture medium, components identical to those found in the leaves of the plants, thus enabling the development and establishment of the pathogen in question [3].

As an example, Pizetta et al. [15] in their study, they tested various means of enriched cultures: ASZV Kuck, SH Schenk and Hildebrandt and HG Harvey and Grasham for the development of Puccinia psidii adapting them extracts Jambeiro sheets (FJ) at four concentrations: $0.5 ; 1.0 ; 3.0$ and $5.0 \mathrm{gL}^{-1}$, concluding that only the first stage of fungal growth was reported, presenting only the growth of germ tubes of the pathogen, not giving segment in its development. Moreover, the same authors also report that only the supplemented culture media showed higher growth of the germ tube of P. psidii were ASZV means HG and FJ at a concentration $0.5 \mathrm{gL}-1$.

Salustiano et al. [16], testing extracts of leaves and an essential oil lamp on urediniospores germination of rust: Puccinia psidii vastatrix Hemileia, pachyrhizi Phakopsora, and Cerotelium fici, concluded that both the treatments, impracticability the germination process urediniospores of Above mentioned rust. Already Capucho et al. [2] were able to maintain the viability of urediniospores in $42 \%$ of $\mathrm{H}$. vastratrix eight months after installation test, using the methodology proposed by the authors, where the ampoules containing the urediniospores collected from infected leaves were sent to the laboratory, sealed in Bunsen burner placed in a beaker and treated with liquid nitrogen following the urediniospores were frozen immediately stored in Ultrafreezer $\left(-80^{\circ} \mathrm{C}\right)$, thereby achieving more efficient preservation $\mathrm{H}$. vastatrix vitro.
Beledelli et al. [17] evaluated the feasibility of Phakopsora pachyrhizi urediniospore in the absence of the host concluded that P. pachyrhizi urediniospore maintain viability by 11 weeks of storage, and still capable of causing infection and symptoms in moderate soybean plants. The methodology used was proposed by the authors with some adaptations carried out in Zambenedetti et al. [5], which was prepared a suspension containing 4.0mg of uredospores of P. pachyrhizi, $1000 \mathrm{ml}$ of sterile distilled water and $0.5 \%$ tween 20, padronizadando in Neubauer chamber to $3.2 \times 104$ urediniósporosmL- ${ }^{1}$ of water, the percentage of germination was verified in water and in agar-water and of infectivity by means of inoculations in soybean plants.

In order to evaluate methods of preservation of uredinióspores of Puccinia kuehnii, Tibolla et al. (B1) [3] with different methods of dehydration and the second one (B2), with different rehydration methods, were used for the treatment B1: 1 - dehydration in silica gel, lyophilization and without dehydration; $\left(-20^{\circ} \mathrm{C}\right)$, deep-freezer $\left(-80^{\circ} \mathrm{C}\right)$, and for $\mathrm{B} 2$ the treatments were: 1$)$ dehydration on silica gel and without dehydration; Room temperature $\left(20^{\circ} \mathrm{C}\right)$, refrigerator $\left(5^{\circ} \mathrm{C}\right)$, freezer $\left(-20^{\circ} \mathrm{C}\right)$ and deep-freezer $\left(-80^{\circ} \mathrm{C}\right)$; With rehydration and without rehydration in the evaluations. The results found by the researchers were as follows: viability decreased as a function of time, with the best treatments reaching $27.6 \%$ and $6.6 \%$ at 30 days, and $12.0 \%$ and $1.9 \%$ at 60 days, For B1 and B2, respectively, since the dehydration method on silica gel followed by storage at $-80^{\circ} \mathrm{C}$ was the only one that presented viable urediniósporos $(1,2 \%)$ at 180 days, for B1 and for treatment B2, the best method was [3]. In the present study, it was observed that the germination rate was higher in the dry season.

\section{Conclusion}

The possibilities of in vitro preservaç will rust for a long period of time is still very vague and there is no precise methodology and concrete about it.

There are some methodologies that allow the preservation of rust, however, for a short period of time.

We still need more studies on these methodologies and their performance in practice in order to achieve a concrete methodology for the preservation of rusts in vitro as well as there is for other microorganisms.

\section{References}

1. Eckardtna (2006) Identification of rust fungi avirulence elicitors. Plant Cell 18: 1-3.

2. Capucho AS, Souza AF, Zambolim EM, Caixeta ET, Rufino RJ, et al. (2005) Feasibility coffee rust uredospore (Hemileia vastatrix Berk. Et Br.) Under different methods of preservation in vitro. In: Coffee Research Symposium of Brazil, n4, 2005, Londrina. Anais ..., Brasília, DF. Embrapa Café.

3. Tibolla F, Sumida CH, Peitl DC, Canteri MG, Castro AMC (2012) In vitro preservation methods urediniospores Puccinia kuehnii. Summa Phytopathologica 38(3): 198-203. 
4. Blum MMC (2009) Phakopsora pachyrhizi sensitivity to fungicides. 2009. Thesis (PhD in Agronomy)-Faculty of Agronomy and Veterinary Medicine, University of Passo Fundo, Passo Fundo, Brazil, p. 173.

5. Zambenedetti EB, Alves E, Pozza EA, Araujo DV (2007) Germination urediniospores Phakopsora pachyrhizi on different storage methods. Summa Phytopathologica 33(1): 83-85.

6. Furtado GQ (2007) Asian soybean rust: urediniospores preservation methods and factors related to infection of the host. 2007. $69 \mathrm{f}$ Thesis (PhD in Agronomy) - University of São Paulo Luiz de Queiroz School of Agriculture, Piracicaba, Brazil.

7. Almeida AMR, Ferreira LP, Yorinori JT, Silva JFV, Henning AA, et al. (2005) Soybean Diseases. In: Kimati H, Amorim L, Rezende Jam, Bergamin Filho A, Camargo La (Eds.), Handbook of Plant Pathology V. 2: diseases of crop plants. (4 ${ }^{\text {th }}$ edn), São Paulo, Agronomic Ceres, Brazil, pp. 569588.

8. Sinclair JB, Hartman Gl (1999) Soybean rust. In: Compendium of soybean diseases. (4 edn), American Phytopathological Society, USA, pp. 3-4.

9. Yang XB, Tschanz AT, Dowler WM, Wang TC (1991). Development of yield loss models in relation to reductions of components of soybean infected with Phakospora pachyrhizi. Journal of Phytopathology 81(11): 420-1426.

10. Hirano M (2009) Production and Germination of spores Phakopsora pachyrhizi in soybean under different environmental conditions. 2009 58 f. Dissertation (Master in Agronomy) - Londrina State University, Londrina, Brazil.
11. Faleiro FG (2011) Scientific principles and genetic analysis using molecular markers. In: Faleiro FG, Andrade SEM (Eds.), Biotechnology: state of the art and applications in agriculture. Planaltina, Embrapa Cerrados, Brazil, p. 730.

12. Matsuo E (2012) Resistance to Asian rust of soybean: hybridization, inheritance and identifying microsatellite markers. 2012. $113 \mathrm{f}$. Thesis (PhD in Agronomy) - Federal University of Viçosa, Viçosa, Brazil.

13. Marcano AD, Vargas N, Pire A (2005) Efecto de vegetal extracts y el synthetic fungicides on in vitro Growth Will mycelial Sclerotium rolfsii Thielaviopsis basicola and. Revista de la Facultad de Agronomia de la Universidad del Zulia, Brazil, 22(4): 315-323.

14. Akamatsu MA, Barreto M, Akamatsu R (2004) Detection and distinction of Phakopsora pachyrhizi and P. meibomiae on herbarium specimens Uredinológico the Biological Institute. Brazilian Phytopathology 29: 277-278.

15. Pizetta M, Pierozzi CG, Pereira GVN, Cruz JCS, Appeared CC, et al. (2016) Studies of three axenic culture media for myrtaceous rust. Summa Phytopathol 42(2): 165-169.

16. Salustiano ME, Ferraz Filho AC, Ampélio Pozza EA, Castro Ha (2006) Extracts lamp (Eremanthus erythropappus (DC.) Macleish) in the in vitro inhibition of Cylindrocladium scoparium and four species of rust. Heart 12(2): 189-193.

17. Beledelli D, Cassetari Neto D, Cassetari Ls, Machado AQ (2012) Urediniospores viability Phakopsora pachyrhizi Sidow in the absence of the host. Bioscience Jounal 28(4): 604-612.

\section{Your next submission with Juniper Publishers will reach you the below assets}

- Quality Editorial service

- Swift Peer Review

- Reprints availability

- E-prints Service

- Manuscript Podcast for convenient understanding

- Global attainment for your research

- Manuscript accessibility in different formats

( Pdf, E-pub, Full Text, Audio)

- Unceasing customer service

Track the below URL for one-step submission https://juniperpublishers.com/online-submission.php 